\title{
Impact of Banking Services on Customer Empowerment, Overall Performance and Customer Satisfaction: Empirical Evidence
}

\author{
S. Amolak Singh ${ }^{1}$, Mrs. B. Anusha ${ }^{2}$, M. Raghuvardhan ${ }^{3}$ \\ Research Scholar, School Of Management Studies, University Of Hyderabad, Gachibowli, Hyderabad, A.P. Pin - 505046. \\ Academic Consultant, Department Of Commerce And Business Management, Satavahana University, Karimnagar, A.P. Pin \\ -505001 . \\ Mba Student, Kakatiya University, Warangal, A.P
}

\begin{abstract}
Customer is not dependent on us. We are dependent on customer (Mahatma Gandhi). Most of the developments taking place in the banking sector have bypassed cooperatives since they are financially not so strong and technically ill-equipped due to aging and not so qualified human resources. The service components of any bank product have a number of unique characteristics which distinguish them from the tangible aspects of the product. The study was undertaken to ascertain the services causes to Customer empowerment, customer satisfaction overall performance of the bank which enhance understanding of consumers' expectations and its role in improving services for customer delight. Data was collected from the fifty one account holders on the bank and to draw valid conclusions multiple regression test was conducted by using SPSS. The findings of this study revealed the services offered by the bank have facilitated moderate in customer empowerment $(C E)$, bank's overall performance (OP) and customer satisfaction (CS).
\end{abstract}

Keywords: Bank Performance, Cooperative Banking, Customer Empowerment, Customer Satisfaction, Customer Service.

\section{Introduction Of Urban Co-Operative Banks (Ucbs):}

The Indian cooperative movement, like its counterparts in other countries of the world has been essentially a child of distress. the Cooperative Credit Societies Act was passed in 1904 based on the recommendations of Sir Frederick Nicholson (1899) and Sir Edward Law (1901) paving the way for the establishment of cooperative credit societies in rural and urban areas on the patterns of Raiffeisen and Schulze Delitzch respectively. The constitutional reforms which led to the passing of the Government of India Act in 1919 transferred the subject of Cooperation from Government of India to the Provincial Governments. The Government of Bombay passed the first State Cooperative Societies Act in 1925 which not only gave the movement its size and shape but was a pace setter of cooperative activities and stressed the basic concept of thrift, self help and mutual aid. This marked the beginning of the second phase in the history of Cooperative Credit Institutions. Since 1950s, the cooperatives in India have made remarkable progress in the various segments of Indian economy. Today, India can claim to have the largest network of cooperatives in the world numbering more than half a million, with a membership of more than 200 million. The village level cooperatives, around 28 percent with 137 million memberships are agricultural cooperatives, dealing directly or indirectly with agricultural sector. Primary (Urban) Cooperative Banks (UCBs) cater to the banking needs of lower/middle class people predominantly comprising businessmen, small traders, artisans, factory workers, salaried persons, etc. in the metropolitan, urban and semi-urban areas. The UCB sector with a population of 1618 UCBs (as on March 31, 2012) is signified by heterogeneity and dichotomy of regulatory control. As many as 1274 (78.7 percent) are small UCBs with deposits not exceeding 20 Million USD with deposits of 10.645 billion. Remaining 344 (21.3 percentage) UCBs are with deposits exceeding 20 Million USD with deposits of 37.050 billion. Most of the developments taking place in the banking sector have bypassed cooperatives since they are financially not so strong and technically ill-equipped due to aging and not so qualified human resources. In order to remedy the situation and bring back the cooperatives to their glory a series of measures to increase efficiency and ability of cooperatives to give better services to rural clients had been initiated by government of India to revitalize the cooperatives.

\section{Perceptions Of Customer Service In Banks:}

Cooperative society has an important role to play as the most suitable medium for the democratization of economic planning. The future of competition lies in an altogether new approach to value creation, based on individual centered creation co-creation of value between consumers and companies. (C.K. Prahald and Venkat Ramaswamy). In the post-nationalisation period the banks elaborate the account of banking in India and large number of measures to improve the system (Saraiya committee, 1972). In 1977, the Talwar committee was constituted and it was it one of earliest committees to study customer services in banks has recommended for 
provision of May I help you counter at branches. The service components of any bank product have a number of unique characteristics which distinguish them from the tangible aspects of the product (Berry) in Indian baking scenario and these services has also played a complementary role in efforts for improving customer service in banks as a result Indian banking association (IBA) had come out with the model fair practices Code (April 1, 2003) covering lenders liability, depositors interests that cover what a customer can expect from his bank. The objective of best customer service can only be achieved through best customer service with support of best strategies is to be applied for identifying the customers and offer them according to their need (G.K Murthy, 2006) is the buzzword and Providing the best customer service evidently depends on employees and their behavior for best delivery(Swartz, Bowen and Brown) because the quality of customer service depend on the human resource practices of the service organizations (Chase, Levit, Roth, and Jackson, Sherman and Gold). To make them innovative in this regard some branches of ABN AMRO bank offer coffee to their customers while discussing their needs and suggesting related products. CITIBANK has separate enclosures for children to play who accompany their parents so that elders can concentrate on baking transactions without disturbance. The working hours of ICICI banks started 8 am to 8 pm banking service. SBI Bank has been functioning even on Sundays (Manoj, 2006). Some banks with a view to ensuring that the service to customers is made available exactly at the commencement of business hours fix the working hours of the staff 15 minutes before the start of business hours. The competitive service market demand the prompt delivery and reaching the expectations are the ladder to enhance the image, create confidence and attract funds at low cost (David Cohen, 2006) and this is quite possible to urban co-operative banks due to their quality of customer service to accomplish the existing gaps in banking and credit needs in urban and semi-urban areas (A. H. Sequeira, 2012) for which they primarily established. Production line approach and empowerment approach (Bowen and Lawler) will be applicable for creating the service quality. customer development cycle is to be formed for personalized communication and offering customized products and services based on what is actually considered good and Once the customer equity is built up bank branches can easily afford cross selling and up-selling. (Vijaya and Suguna, 2006).

\section{Perceptions Of Customer Empowerment:}

Consumer empowerment is defined as the power of resources offered by organization in the form of information understanding to consumer (Brennan and Ritters 2004, Clutter and Nye 2000). It is also stated as a positive subjective condition provided by increased control (Wathieu et.al, 2002), but it cannot be defined as control. The advent of technology available in the market has providing the several opportunities to marketers in translating consumers into empowered consumer. As a part of consumer awareness programs sources like government agencies and consumer education are active role players. The questions like how much marketers offer empowerment to consumer is to be assessed properly for the effective use of this tool as competitive advantage. Several discussions are made by researchers and academicians on the same issue and suggested empowerment is significantly necessary to face the upcoming competition and it has been identified as a growing force in marketing. Though empowerment is identified as subjective understanding of consumers about their increased capability compared to earlier by which they can consciously construct required results and prevent undesired. Thus empowerment is treated as reminder of increased ability to manage and sometimes may be experience to verify whether ability is really increased or not. In the competitive market conditions to survive knowing the conditions under which the relationship between consumer empowerment and satisfaction would be reinforced is requisite for marketer.

\section{Perceptions Of Over All Performance:}

Organizational performance is to be carefully measured for which periodic employee and customer surveys would be initiative for improvement - Gene Ference, President - The Ference Group. Decisions taken by management, economic conditions and balance-sheets clearly state the performance. The report of work completed and performance would become a useful assistance to estimate sufficient earnings, capital, asset and liability management, capital and management escalation. Bankers and its management can utilize repots for future references to understand bank's financial condition and serve better. The competency of all services of bank and its impact on performance need to be measured in monetary and financial environment are the major issues and cannot be measures easily. Since intangible nature of services various researchers have attempted studies to determine the productivity and competence of the banking industry using outputs, costs, efficiency and performance. The bank performance measurement using normal correlation analysis including multidimensional indexes of portability, loan market share and pricing of bank services was studied by (Arshadi and Lawrence, 1987) and confirmed the in the new competitive environment there are fair chances to survival of large banks. Where as the matter of survival of small banks depends on their specialized or unique activities (Peterson and Rajan,1995). 


\section{Perceptions Of Customer Satisfaction:}

Many studies have proved the customer satisfaction is significant to reach the bottom line and it is possible when the service performance show positive impact on custmoer intangible expectations. Researchers are even proved that there is positive correlation exists between quality in service and satisfaction (Vijay and Selvaraj, 2012). Today companies are found customer satisfaction as significant indicator for strategic success of the business. Hence they are interested in valuing, measuring and tracking of customer satisfaction for superior managerial performance leads to sustain and this could include the better understanding of customer expectations to draw road map to accomplish their needs. Improved customer empowerment is allied with improved customer satisfaction. The banks enabled themselves to offer several services but satisfaction lies in accomplishment of need of customer. It is like hunger needs bread and butter and blind needs vision.

\section{Literature Review:}

A large scale survey on customer service climate of banking sector in India revealed that banks which were low on the performance, profitability and productivity were perceived by their employees as low in customer service. (National Institute of Bank management, 1983). Firms which deliver best quality and products always came up and top. The reason for success is the quality of customer service of the firm and not the advertisement slogans (B. Uttal 1987). Providing customers with a checklist on what is expected from them to serve them better will go a long way in making things easy for all (Parthasarathi, 2006). Berry and Brodeur between 1990 -1998 defined ten 'Quality Values' which influence satisfaction behavior, further expanded by Berry in 2002 identified service behaviors are one of the important influencer for satisfaction. This factor is stressed for continuous development and frequently utilized to improve the architecture for satisfaction measurement.

The Ouschan, Sweeney and Johnson 2006 in their study found the patients are more trusting of and committed to physicians who adopt an empowering communication style with them. The study conducted by the jean and paul 2003 found the empowerment is a very efficacious managerial control tool in that it significantly affects the behavior and attitudinal dispositions of boundary-spanning service employees. Quantitative analysis based on multivariate analysis techniques indicates that empowerment practices when simultaneously implemented have a favorable effect on employee well being, productivity, performance and service quality. (Geralis and Terziovski 2003). It has been argued and shown that firms empowering their customers can generate better products at lower cost and risk if customers are willing and able to deliver value. Empowerment strategies might be used to improve a firm's corporate associations as perceived by the broad mass of potential customers (Christoph and Martin 2011). While there is evidence as to when consumer empowerment is beneficial for the consumer (Goldsmith 2005, Pitt et.al, 2002) less well known is when giving control to consumer offers potential benefits to marketers.

In the study conducted by Victoria and Andres, 2008 found the employees are more likely to improve their general performance and are more cooperative when internal service quality exists. Kuin, 1999 has identified the level of internal service quality experienced by the staff in the main delivery systems can enhance firm's overall quality performances. Milan and Martina, 2008 has found the service performance and organization mission of the service organization predict customer satisfaction based on established and proven health services. Banks appeared to provide additional or higher quality services that raised costs but also raised revenues by more than the cost increases. The results suggest that methods that exclude revenues when assessing performance may be misleading (Allen N. Berger, Loretta J. Mester, 2003). The prevailing manufacturing strategy framework can be adopted in service strategy delivery system design and the moderating role that customer contact exerts in service strategy formation (Roth and Velde, 1991). The results indicate that IT-based services have a direct impact on the SERVQUAL dimensions and an indirect impact on customer perceived service quality and customer satisfaction (Zhu, Wymer and Chen, 2002). There is considerable evidence that service quality functions as antecedent to customer satisfaction (Reidenbach et.al,1990, Cronin and Taylor 1992).

According to Zairi, 2000 internal customer satisfaction is the source of excellent quality because if the organization satisfies the needs of it's internal customers. It is also enabling internal customer s to perform their tasks and networks of organization units are more likely to work effectively together to achieve customer satisfaction. Reichheld 2003, proposed the high levels of satisfaction leads to increased customer loyalty. They also indicate that increased customer loyalty is the single most important drives of long-term financial health, recent studies are also affirm that customer satisfaction leads to customer retention (Hallowell 1996). if having satisfied customers was all it took to grow, banks would be In heaven (Lakshminarasimha and Murali, 2006) which improves the quality of customer service therefore plays a pivotal role (G.K Murthy, 2006) in the prosperity of a bank. Parasuraman, et.al, between 1985 to 1988 offered the root for the customer satisfaction measurement by way of a service gap between the expected and observed customer performance. 


\section{Need For The Study:}

Urban Co-operative Banks (UCBs) are an important part of the financial system in India. Offering superior services can help firms become more profitable and help them sustain a competitive advantage (Hampton, 1993) in their served markets as well as banks have realized that customer service should be the goal of all the banking employees regardless of their domain, status or area of specialized work (Manoj, 2006). Most Indian banks are increasingly realizing the fact that the cost of acquiring the new customer is far higher than cost of retaining the existing ones and a customer can now go elsewhere if they don't get what they want. Continuous improvement, gaining the competitive edge, increased market share and higher profits are not possible unless business can find new ways of maintaining the services for existing customer. Once the satisfactory service extended, the service itself works like a brand for the bank. In order to create a brand the technique of customer centric banking is to be implemented. Growing customer expectations and new delivery channels are the concern of each and every bank today (Vijaya and Suguna, 2006). Banks need to find new value in existing systems as well as ways to explore new market opportunities and relentlessly improve the quality of product and services with improved technology. (V.V. Sai, 2006). Before service improvement programs are introduced, current service quality levels are needed to be addressed (Bery and Parasuraman, 1991) by applying scientific method for reducing the time (Manoj, 2006) to attend the customer without compromising on the quality. The continuous research analysis and improvements over long period results in enhancing customers life time value (V.V. Gopal 2006) with the firm. It is imperative (Very Important) that the banks identify and understand the customer needs for the benefit of customer satisfaction and delight (V.V. Sai, 2006). The dimensions of the customer service aspects for judging service directly depends on service provider and they arise out of the organizational policies of the bank (V.A. Zeithaml, A Parasuraman and L.L Berry) because the service oriented firms in their pursuit of service quality need to create climate for service and climate for employee well being (Schneider and Bowen). The purpose of this study is to diagnose services offered by KUCB and assessing and comparing the perceptions of consumers. It will enhance understanding of consumers expectations and its role in improving service quality (Parasuraman et al., 1994). To maintain the KUCB as it established for along with continuous emergence of sound and healthy banking services essentially to the middle and lower middle classes and marginalized sections of the society.

\section{OBJECTIVES:}

1. To ascertain the services causes to Customer empowerment, overall performance and customer satisfaction of the bank.

2. To ascertain the nature and extent of services impact on Customer empowerment, overall performance and customer satisfaction of the bank.

\section{HYPOTHESES:}

$\mathbf{H}_{1}$ : Customers are not empowered from customer services offered by bank.

$\mathbf{H}_{2}$ : The offered services do not facilitate to improve the bank's overall performance.

$\mathbf{H}_{3}$ : Customers perceive the services do not satisfy them.

$\mathbf{H}_{4}$ : Customer service perceived as low in KUCB and results in low customer empowerment, customer satisfaction and overall performance.

\section{Research Methodology:}

The study: The descriptive research study was initiated to find out the services offered by the bank and its role on the customer empowerment which leads to customer satisfaction and finally improves the bank's performance. The selection of services is based on the literature of banking services which were compared with services offered by Karimnagar urban co-operative bank and which were researchable in the bank are selected.

The Sample: Non probability sampling technique was used in the research in which sample was collected on convenience basis.

Sample Size: A sample size is fifty one account holders of the bank.

Data collection: The data collected through self developed questionnaire. Author procured information regarding offered services from bank. The services which are received by the customers are selected in the final questionnaire. The questionnaires were supplied in front the bank gate but most of the account holders was refused to communicate and few customers shown their interest to give response. For each statement of the questionnaire the respondents are asked to indicate their opinion.

Data analysis: To draw valid conclusions and test them empirically, before starting the regression test the data was tested using Cronbach's alpha test is also used to test reliability. Later data was tested using mean, median and mode to check the symmetry of data and found data are partially asymmetry. The multiple linear regression tests was conducted which includes the ANOVA. All these tests are conducted using SPSS. 


\begin{tabular}{|c|c|c|c|c|c|c|}
\hline SL.NO & Services & Independent & Mean & Median & Mode & $\begin{array}{l}\text { Alpha } \\
\text { Value }\end{array}$ \\
\hline 1 & Email \& Prospectus & $\mathrm{X}_{1}$ & 3.49 & 4 & 4 & 0.9333 \\
\hline 2 & Phone Calls & $\mathrm{X}_{2}$ & 3.41 & 4 & 4 & 0.9212 \\
\hline 3 & Messages \& Post & $\mathrm{X}_{3}$ & 3.29 & 3 & 3 & 0.9432 \\
\hline 4 & Difficulty during visit & $\mathrm{X}_{4}$ & 4 & 4 & 4 & 0.8337 \\
\hline 5 & Client History & $\mathrm{X}_{5}$ & 1 & 1 & 1 & 0.8337 \\
\hline 6 & Delivering on Promises & $\mathrm{X}_{6}$ & 1 & 1 & 1 & 0.8337 \\
\hline 7 & New services \& Policies & $\mathrm{X}_{7}$ & 1.71 & 2 & 1 & 0.9287 \\
\hline 8 & Clear details & $\mathrm{X}_{8}$ & 1 & 1 & 1 & 0.8337 \\
\hline 9 & Clear requests \& Doubts & $\mathrm{X}_{9}$ & 1.73 & 2 & 2 & 0.9281 \\
\hline 10 & Time to complete Job & $\mathrm{X}_{10}$ & 1.35 & 1 & 1 & 0.9451 \\
\hline \multicolumn{7}{|c|}{ Mean, Median, Mode rating and Cronbach's Alpha values of Dependent Variables } \\
\hline SL.NO & Variables & Dependent & Mean & Median & Mode & $\begin{array}{l}\text { Alpha } \\
\text { Value }\end{array}$ \\
\hline 11 & Customer Empowerment & $\mathrm{Y}_{1}$ & 1.55 & 2 & 2 & 0.8985 \\
\hline 12 & Bank Overall Performance & $\mathrm{Y}_{2}$ & 1.41 & 1 & 1 & 0.8958 \\
\hline 13 & Customer Satisfaction & $\mathrm{Y}_{3}$ & 1.45 & 1 & 1 & 0.8970 \\
\hline
\end{tabular}

The test shown the data is normal or non normal. The Cronbach alpha values of table no 1 which is higher than the benchmark (Cronbach alpha $>0.70$ as suggested by nunally, 1978). This indicates the data would be utilized for further analysis.

Model: Customer Empowerment $=\boldsymbol{\alpha}+\boldsymbol{\beta}_{\mathbf{1}}$ Email \& Prospectus $+\boldsymbol{\beta}_{\mathbf{2}}$ Phone Calls $+\boldsymbol{\beta}_{\mathbf{3}}$ Messages \& Post $+\boldsymbol{\beta}_{\mathbf{4}}$ Delivering on Promises $+\boldsymbol{\beta}_{5}$ New services $\&$ Policies $+\boldsymbol{\beta}_{\mathbf{6}}$ Clear details ${ }_{+} \boldsymbol{\mu}$.

\begin{tabular}{|c|c|c|c|c|c|}
\hline \multicolumn{6}{|c|}{ Table 2: MULTIPLE REGRESSION OF CUSTOMER EMPOWERMENT } \\
\hline Summary & Multiple R & $\mathbf{R}^{2}$ & Adjusted $\mathbf{R}^{2}$ & $\begin{array}{c}\text { Std. Error Of } \\
\text { Estimate }\end{array}$ & \\
\hline & 0.934 & 0.873 & 0.848 & 0.196 & \\
\hline ANOVA Table & $\begin{array}{c}\text { Sum of } \\
\text { Squares }\end{array}$ & df & Mean squares & F- Ratio & p-Value \\
\hline Explained & 11.018 & 8 & 1.377 & 35.940 & 0.000 \\
\hline Unexplained & 1.609 & 42 & 0.038 & & \\
\hline Regression Table & Coefficient & $\begin{array}{c}\text { Standard } \\
\text { Error }\end{array}$ & t-Value & p-value & \\
\hline Constant & 0.424 & 0.447 & -0.947 & 0.349 & \\
\hline Email \& Prospectus & 0.337 & 0.131 & 2.576 & 0.014 & \\
\hline Phone Calls & 0.237 & 0.128 & 1.856 & 0.071 & \\
\hline Messages \& Post & -0.144 & 0.101 & -1.421 & 0.163 & \\
\hline Delivering on Promises & 0.302 & 0.216 & 1.394 & 0.171 & \\
\hline New services \& Policies & 0.240 & 0.081 & 2.949 & 0.005 & \\
\hline Clear details & -0.368 & 0.231 & -1.592 & 0.119 & \\
\hline Clear requests $\&$ Doubts & 0.002 & 0.090 & 0.019 & 0.985 & \\
\hline Time to complete job & 0.086 & 0.108 & 0.798 & 0.429 & \\
\hline
\end{tabular}

\section{Author's Calculation}

R-square value is 0.873 was obtained which implies that 87.3 percent of variation is observed in customer empowerment. This is quite high. The calculated F-ratio value 35.940 is greater than critical value 2.1681. Hence we reject hypothesis $\mathrm{H}_{1}$ which means the services offered by the bank have empowered the customer. The positive variation attributed by Email \& Prospectus, Phone Calls, Delivering on Promises, New services \& Policies, Clear requests \& Doubts and Time to complete job have accounted the variation in the test. Thus it implies that one unit increase in these services causes to increase in customers' empowerment by 0.337 , 
$0.237,0.302,0.240,0.002$ and 0.086 units respectively. Whereas the messages, post and clear details have accounted the negative variation in the test. Thus it implies that one unit increase in these services causes to decrease in customer empowerment by -0.114 and -0.368 units respectively.

Model: Overall Performance $=\boldsymbol{\alpha}+\boldsymbol{\beta}_{\mathbf{1}}$ Email \& Prospectus $+\boldsymbol{\beta}_{\mathbf{2}}$ Phone Calls $+\boldsymbol{\beta}_{\mathbf{3}}$ Messages \& Post $+\boldsymbol{\beta}_{\mathbf{4}}$ Delivering on Promises $+\boldsymbol{\beta}_{5}$ New services \& Policies $+\boldsymbol{\beta}_{6}$ Clear details $+\boldsymbol{\beta}_{7}$ Clear requests \& Doubts $+\boldsymbol{\beta}_{\mathbf{8}}$ Time to complete job $+\mu$.

\begin{tabular}{|c|c|c|c|c|c|}
\hline \multirow[t]{2}{*}{ Summary } & Multiple R & $\mathbf{R}^{2}$ & Adjusted $\mathbf{R}^{2}$ & $\begin{array}{c}\text { Std. Error Of } \\
\text { Estimate }\end{array}$ & \\
\hline & 0.939 & 0.882 & 0.860 & 0.186 & \\
\hline ANOVA Table & $\begin{array}{c}\text { Sum of } \\
\text { Squares }\end{array}$ & df & Mean squares & F- Ratio & p-Value \\
\hline Explained & 10.901 & 8 & 1.363 & 39.411 & 0.000 \\
\hline Unexplained & 1.452 & 42 & 0.035 & & \\
\hline Regression Table & Coefficient & $\begin{array}{c}\text { Standard } \\
\text { Error }\end{array}$ & t-Value & p-value & \\
\hline Constant & 0.362 & 0.425 & 0.852 & 0.399 & \\
\hline Email \& Prospectus & 0.102 & 0.124 & 0.823 & 0.415 & \\
\hline Phone Calls & -0.230 & 0.121 & -1.896 & 0.065 & \\
\hline Messages \& Post & 0.419 & 0.096 & 4.364 & 0.000 & \\
\hline Delivering on Promises & 0.207 & 0.205 & 1.008 & 0.319 & \\
\hline New services \& Policies & 0.121 & 0.077 & 1.562 & 0.126 & \\
\hline Clear details & -0.199 & 0.220 & -0.904 & 0.371 & \\
\hline Clear requests \& Doubts & 0.018 & 0.085 & 0.216 & 0.830 & \\
\hline Time to complete job & 0.423 & 0.102 & 4.131 & 0.000 & \\
\hline \multicolumn{6}{|c|}{$\begin{array}{l}\text { NOTE: Predictors in the Model: (Constant), Time takes to complete job, Bank delivering the services on promises, Bank is } \\
\text { maintaining clear details of accounts, Customers receive phone calls, Employees respond to your requests and doubts, } \\
\text { employees explain about New services and policies, Customers receive Messages and post, Email and Prospectus; Dependent } \\
\text { Variable: Overall Performance. } \\
\text { 1) Critical value calculated at } 5 \text { percent level of significance. }\end{array}$} \\
\hline
\end{tabular}

\section{Author's Calculation}

The high R-square value is 0.882 was obtained which implies that 88.2 percent of variation is observed in overall performance of the bank. The calculated F-ratio value 39.411 is greater than critical value 2.1681. Hence we reject hypothesis $\mathrm{H}_{2}$ which means services offered by the bank have facilitated to improve bank's performance. The positive variation attributed by Email \& Prospectus, Messages \& Post, Delivering on Promises, New services \& Policies, Clear requests \& Doubts and Time to complete job have accounted the variation in the test. Thus it implies that one unit increase in these services causes to increase in bank's overall performance by $0.102,0.419,0.207,0.121,0.018$ and 0.423 units respectively. Whereas, the phone calls and clear details has accounted the amount of negative variation in the test. Thus it implies that one unit increase in these services causes to decrease in overall performance of the bank by -0.230 and -0.199 units respectively. The predators of bank's performance have shown the significant variation.

Model: Customer Satisfaction $=\boldsymbol{\alpha}+\boldsymbol{\beta}_{\mathbf{1}}$ Email \& Prospectus $+\boldsymbol{\beta}_{\mathbf{2}}$ Phone Calls $+\boldsymbol{\beta}_{\mathbf{3}}$ Messages \& Post $+\boldsymbol{\beta}_{\mathbf{4}}$ Delivering on Promises $+\boldsymbol{\beta}_{5}$ New services $\&$ Policies $+\boldsymbol{\beta}_{6}$ Clear details $+\boldsymbol{\beta}_{7}$ Clear requests $\&$ Doubts $+\boldsymbol{\beta}_{\mathbf{8}}$ Time to complete job $+\boldsymbol{\mu}$.

\begin{tabular}{|c|c|c|c|c|c|}
\hline \multirow[t]{2}{*}{ Summary } & Multiple R & $\mathbf{R}^{2}$ & Adjusted $\mathbf{R}^{2}$ & $\begin{array}{c}\text { Std. Error Of } \\
\text { Estimate }\end{array}$ & \\
\hline & 0.925 & 0.855 & 0.827 & 0.209 & \\
\hline ANOVA Table & $\begin{array}{c}\text { Sum of } \\
\text { Squares }\end{array}$ & df & Mean squares & F- Ratio & p-Value \\
\hline Explained & 10.796 & 8 & 1.350 & 30.954 & 0.000 \\
\hline Unexplained & 1.831 & 42 & 0.044 & & \\
\hline Regression Table & Coefficient & $\begin{array}{l}\text { Standard } \\
\text { Error }\end{array}$ & t-Value & p-value & \\
\hline Constant & 0.339 & 0.477 & -0.711 & 0.481 & \\
\hline Email \& Prospectus & 0.157 & 0.140 & 1.125 & 0.267 & \\
\hline Phone Calls & -0.209 & 0.136 & -1.535 & 0.132 & \\
\hline Messages \& Post & 0.432 & 0.108 & 4.002 & 0.000 & \\
\hline Delivering on Promises & 0.265 & 0.231 & 1.149 & 0.257 & \\
\hline
\end{tabular}




\begin{tabular}{|c|c|c|c|c|c|}
\hline New services \& Policies & 0.231 & 0.087 & 2.669 & 0.011 & \\
\hline Clear details & -0.349 & 0.247 & -1.415 & 0.164 & \\
\hline Clear requests \& Doubts & -0.007 & 0.096 & -0.068 & 0.946 & \\
\hline Time to complete job & 0.172 & 0.115 & 1.500 & 0.141 & \\
\hline \multicolumn{6}{|c|}{$\begin{array}{l}\text { NOTE: Predictors: (Constant), Time takes to complete job, Bank delivering the services on promises, Bank is maintaining } \\
\text { clear details of accounts, Customers receive phone calls, Employees respond to your requests and doubts, employees explain } \\
\text { about New services and policies, Customers receive Messages and post, Email and Prospectus; Dependent Variable: Customer } \\
\text { Satisfaction. } \\
\text { 1) Critical value calculated at } 5 \text { percent level of significance. }\end{array}$} \\
\hline
\end{tabular}

\section{Author's Calculation}

The high R-square value is 0.855 was obtained which implies that 85.5 percent of variation is observed in customer satisfaction. The calculated F-ratio value 30.954 is greater than critical value 2.1681 . Hence we reject hypothesis $\mathrm{H}_{3}$ which means services offered have satisfied the customer. The positive variation attributed by Email \& Prospectus, Messages \& Post, Delivering on Promises, New services \& Policies, and Time to complete job have accounted the variation in the test. Thus it implies that one unit increase in these services causes to increase in customer satisfaction by $0.157,0.432,0.265,0.231$ and 0.172 units respectively. Whereas, the Phone Calls, clear details and Clear requests \& Doubts has accounted the amount of negative variation in the test. Thus it implies that one unit increase in these services causes to decrease in customer satisfaction by -0.209 , -0.349 and -0.007 units respectively. The predators of customer satisfaction have shown the significant variation.

\section{FINDINGS:}

1) There is a significant variation has shown by bank's services to explain three predictors of the study with $R^{2}$ values are greater than 85 percent.

2) Karimnagar urban cooperative bank services email \& prospectus and delivering promises have observed as most significant for customer empowerment.

3) Offered services like completing the work within stipulated time, by sending messages \& post and delivering the services as promised are identified as most considerable reasons for increasing in bank's performance.

4) Timely sent messages \& post service has highly shown impact on customer satisfaction.

\section{Conclusions:}

The cooperative society emerged a means for value creation and vital role to play economic development of the rural India. The customers are now more concerned with the services rather than products. In the present scenario customer delight has been the buzzword in the banking. The predators have shown the significant variation in customer empowerment, bank's overall performance and customer satisfaction (Geralis and Terziovski 2003). The study proved the bank is providing the high customer service and the $\mathrm{R}^{2}$ values for the multiple regression analysis for customer empowerment, overall performance and customer satisfaction are greater than 0.85 . This high value indicates the services have caused quite high in dependent variables hence we reject the $\mathrm{H}_{4}$ hypothesis. Offered services shown its impact differently in the customer empowerment, overall performance and customer satisfaction. Empowerment would be a positive link for satisfaction and become a competitive advantage. Table no. 2 is the evidence for the predators positively and negatively affects the constant. Among these email \& prospectus and delivering promises has majorly influenced the customer empowerment where as new services \& policies and phone calls have moderately caused. When the bank is unable to provide the clear details, it has majorly caused to reduce the customer empowerment. The impact of these services on customer empowerment proved hence we reject hypothesis $\mathrm{H}_{1}$. Table no 3 confirm the increased bank's performance was majorly influenced by completing the work within stipulated time, by sending messages \& post and delivering the services as promised. Whereas, the bank's performance have moderately reduced by phone calls service and problems faced in providing the clear details. The services has affected the bank's overall performance hence we reject $\mathrm{H}_{2}$ hypothesis. The fast growth of population has escalated the demand for banking transactions and services too. Providing the service with speed would become the important differentiator for each bank. Table no 4 illustrate the messages \& post service has influenced majorly for customer satisfaction whereas delivering services within time and explaining about new policies and services has moderately influenced. The satisfaction levels have reduced due to providing the unclear details and by phone calls services. Customer satisfaction has influenced by the services thus we reject $\mathrm{H}_{3}$ hypothesis. The satisfaction leads to positive word of mouth which may cause to enhanced financial performance of the bank (Anderson et.al, 1997). 
Aknowledgement

We owe a great many thanks to many people who helped and supported us during the writing of this research paper. Our hearty thanks to the Karimnagar Urban Co-operative bank and its staff who permitted us to conduct the research on banking services entitled "Impact Of Banking Services On Customer Empowerment, Overall Performance And Customer Satisfaction: Empirical Evidence”.

We also thank to the respondents who have given their valuable time to fill the questionnaire. Without whom the research was not possible.

We would like to thank our friends, parents and all the supporters to provide their valuable suggestions and guidance at all stages which helped us to successfully complete the work.

\section{References:}

[1]. Aleda V. Roth and Marjolijn Van Der Velde, Operations as marketing: A competitive service strategy, Journal of Operations Management, Volume 10, Issue 3, August 1991, Pages 303-328.

[2]. Allen N. Berger, Loretta J. Mester, Erratum to Explaining the dramatic changes in performance of US banks: Technological change, deregulation, and dynamic changes in competition Journal of Financial Intermediation. 12 (2003) 57-95.

[3]. Bipinchandra T. Vadhar, 2011, A Study on Governance Practices in Cooperative Banks, PhD thesis, Saurashtra University.

[4]. Deepti and Yadav, Customer Satisfaction in Commercial Banks A Case Study of Punjab National Bank, International Journal of Trade and Commerce, January-June 2012, Volume 1, No. 1, pp. 90-93.

[5]. Christoph Fuchs, Martin Schreier Customer Empowerment in New Product Development, Journal of Product Innovation Management, Volume 28, Issue 1, pages 17-32, January 2011

[6]. Dr Partho Pratim Roy, Management of Urban Co- Operative Bank (1/e), Himalaya,

[7]. Dr. A. H. Sequeira (2012), Customer Services in Co-Operative Banks: A Case Study, Social science research network, My 25, 2012, pp: 24-26.

[8]. $\quad$ Faye X. Zhu, Walter Wymer, Injazz Chen, (2002) "IT-based services and service quality in consumer banking", International Journal of Service Industry Management, Vol. 13 Iss: 1, pp.69 - 90.

[9]. Guttman, L. (1945). A basis for analyzing test-retest reliability. Psychometrika, 10, 255-282

[10]. G. Gopala Krishna murthy (2006). Customer service in India banks - An overview (1/e). Icfai university press.

[11]. http://indiancooperative.com/lawslegislations/vaidyanathan-committee-report-to-be-implemented-soon/, Posted on 30 August 2011 by Ajay Jha.

[12]. http://www.rbi.org.in/scripts/fun_urban.aspx

[13]. Jean-Charles Chebat, Paul Kollias, The Impact of Empowerment on Customer Contact Employees' Roles in Service Organizations, , Journal of Service Research, August 2000 vol. 3 no. 1, PP. 66-81.

[14]. Johnston R, 1997, The international Journal of bank marketing Vol. 15, Number 4, September 1997, pp: 111-116).

[15]. K. Kosmidou, C. Zopounidis, Measurement Of Bank Performance In Greece, South-Eastern Europe Journal of Economics - 1 (2008), pp:79-80.

[16]. Michelle Geralis \& Mile Terziovski, A quantitative analysis of the relationship between empowerment practices and service quality outcomes, Total Quality Management \& Business Excellence, Volume 14, Issue 1, 2003 , pages 45-62.

[17]. Nunally J.C. (1978). Psychometric Theory (1/e). Newyork: McGrawHill.

[18]. Robyn Ouschan, Jillian Sweeney, Lester Johnson, (2006) "Customer empowerment and relationship outcomes in healthcare consultations", European Journal of Marketing, Vol. 40 Issue: 9/10, pp.1068 - 1086.

[19]. Shivajirao, Report of the High Powered Committee on Cooperatives(2009), Ministry of Agriculture Government of India, pp:5360 .

[20]. S. Vijay Anand, M. Selvaraj, The Impact of Service Quality on Customer Satisfaction and Loyalty in Indian Banking Sector: An Empirical Study through SERVPERF, International Journal of Management business Research 2 (2), 151- 163, Spring 2012.

[21]. The Indian Central Banking Enquiry Committee, Calcuctta: Government Of India Central Publica'l'ion Branch, Volume - I, 1931, pp: 42-58. 